\title{
ポリカルボシランの熱分解反応によって 合成される炭化ケイ素
}

\author{
川村和郎*・藤本司郎*・岩田富雄** \\ 山中清二**. 丸軍二郎 ${ }^{* *} \cdot$ 尾野幹也**
}

(平成元年 9 月13日受理)

\section{Preparation of Silicon Carbide from Pyrolysis of Carbosilane Polymer}

\author{
Kazuro Kawamura*, Shiro Fujimoto*, Tomio Iwata**, \\ Seiji Yamanaka**, Gunjiro Maruyama** and Mikiya Ono** \\ *Dept.of Materials Science and Engineering, \\ The National Defense Academy, 1-10-20, \\ Hashirimizu, Yokosuka 239 \\ **Mitsubishi Mining and Cement Co., Ltd., \\ Yokoze-cho, Chichibu-gun, Saitama-ken, 368
}

The porous and crosslinked polycarbosilane with a powerful affinity for oxygen was obtained by the pyrolysis of polydimethylsilane in $\mathrm{N}_{2}$ gas atmosphere. This polycarbosilane was converted to silicon carbide by heat-treating at the temperatures from 1200 to $1400^{\circ} \mathrm{C}$ in $\mathrm{N}_{2}$ gas atmosphere, and quartz was formed as a by-product. The addition of polyvinyl butyral as a carbon source to polycarbosilane prevented quartz formation. The chemical analysis of silicon carbide showed that the ratio of $\mathrm{Si}$ to $\mathrm{C}$ was not theoretical but $\mathrm{C}$ content was larger than Si. As the temperature rose, the ratio of $\mathrm{Si}$ to $\mathrm{C}$ approached theoretical value, and free carbon content increased.

KEYWORDS: Polycarbosilane, Silicon carbide

\section{1. 緒言}

有機物を出発原料とし，乙れを加熱処理して無機化す ることによって製造される材料の代表例は炭素材である。 乙の手法で有機金属化合物からセラミックス材を合成す る研究が1964年頃から抢てなわれている11。有機ケイ素 化合物であるポリカルボシランから炭化ケイ素を合成す る研究は1970年代に始まっている ${ }^{2)}$ 。特に有名な合成方 法は矢島プロセスとして知られ，次の工程から成る。 まず，ジメチルジクロロシランと金属ナトリウムとの

*防衛大学校材料物性工学教室: $\mathbf{T} 239$ 横須賀市走水1$10-20$

**三菱鉱業セメント (株)セラミックス研究所 : $\mathbf{T} 368$ 埼 玉県秩父郡横瀬町大字横瀬 2270
脱塩素反応によってポリジメチルシランが合成される。 ポリジメチルシランは不活性ガス雾囲気中での熱重合に よってポリカルボシランに変換される。ポリカルボシラ ンは, 細い系状に成形され, $200^{\circ} \mathrm{C}$ 近傍の温度で酸化処 理され不融化される。乙の前駆体の焼成によって炭化ケ イ素連続繊維が得られる ${ }^{3)}$-6)。

この製造方法はポリアクリロニトリルやピッチからの 炭素繊維の製造方法とほとんど同じである。工業規模で 生産されている両繊維の特性, 例えば強度や弾性率を比 較しても大差があるようには見えないが7), 耐酸化性は 両繊維で著しく異なる。炭化ケイ素繊維は空気中 1250 ${ }^{\circ} \mathrm{C}$ の高温に耐えることができる ${ }^{7)}$ 。このように炭化ケイ 素繊維は炭素繊維で達成できない長所を有するために, 繊維強化セラミックス (FRC) や繊維強化金属 (FRM) 
などの複合材としての利用が期街されている。

ポリジメチルシランに車命促進剤として少量のポリボ ロジフェニルシロキサンを加え, 窒素ガス霝用気巾350 $\sim 400^{\circ} \mathrm{C}$ で熱重合させ，反応時間变化住対して得られる 重合物を観祭すると，低重合物は粘稠な液体状，さらに 重命が進行したものは常埧で脆い固体状で，乙の重合物 はベンゼンやキシレンに叮溶である。さらに重合を進め ると発泡状となり, 乙の重合物は溶媒に不溶で, 加熱し ても溶融しない。可溶, 可融の性質を有するポリカルボ シランは炭化ケイ素連続繊維の前駆体ポリマーとして利 用されるために，てのポリマーの熱分解過程に関しての デー夕は多い ${ }^{8)}$ 。一方, 最終的な重合形態である三次元 構造の発泡状ポリカルボシランは利用方法が見出されて いなかったために，その性質や炭化ケイ素への変換過程 に抢ける構造変化に関してのデータは少ない。本報告は, この最終形態の発泡状のポリカルボシランの構造上の特 徵や炭化ケイ素への変換時の挙動に関して知見を得るて とを目的とする。

\section{2. 実験}

\section{1 試 料}

ジメチルジクロロシランは東芝シリコーン製品 (bp.70 $\sim 71^{\circ} \mathrm{C}$, 比重 1.06) を, ジフェニルジクロロシランは同 社製品（bp. $309 \sim 310^{\circ} \mathrm{C}$, 比重 1.22 ）を使用した。金属 ナトリウムは和光純薬工業製品（化学用, 棒状）を使用 した。キシレンは和光純薬工業製品を金属ナトリウムで 脱水後蒸留精製して使用した。

\section{2 加熱処理と物性測定}

加熱处理は以下のようにしておてなった。

アルミナボートに試料の少量を採取し，管状炉を使用 して窒素ガス需囲気下 $1200 \sim 1400{ }^{\circ} \mathrm{C}$ の範囲で加熱処 理した。最高温度での保持時間は 1 時間とした。

溶剂に可溶であるポリカルボシランの分子量はベンゼ ンの希薄溶液（1～6 $\mathrm{wt} \%)$ についてベックマン温度計 を用いて凝固点降下法で次式から求め, 濃度 0 亿外そう した值を分子量とした。

$$
\mathrm{M}_{\mathrm{n}}=\mathrm{K}_{\mathrm{f}} \cdot 1000 \cdot \mathrm{S} /\left(\mathrm{B} \cdot \Delta \mathrm{T}_{\mathrm{f}}\right)
$$

ここで, $\mathrm{M}_{\mathrm{n}}$ は数平均分子量, $\mathrm{K}_{\mathrm{f}}$ はベンゼンのモル凝固 点降下定数, $\mathrm{S}$ は試料の重量, $\mathrm{B}$ はベンゼンの重量, $\Delta \mathrm{T}_{\mathrm{f}}$ は凝固点降下を示す。

IR スペクトルは日立製作所製 IR - G 型赤外分光計を 使用して, KBr 錠剂法で測定した。

熱分析は荀津製作所製示差熱分析装置を使用し, 白金 製容器に $10 \mathrm{mg}$ の粉末試料をとり, 窒素ガス雾囲気中で $20^{\circ} \mathrm{C} / \mathrm{min}$ で昇温して熱重量分析 ( $\mathrm{TG}$ ) 之示差熱分析 (DTA）を同時汇打てなった。
$\mathrm{X}$ 線回折は理”兴電気製回転刘陰極形超強力 $\mathrm{X}$ 線回折 装䇺! (ローターフレックス RU-200) を使用し, 電压40 $\mathrm{kV}$ ，電流 $100 \mathrm{~mA}, \mathrm{CuK} \alpha$ 線で抢こなった。

密度は粉末状態の試料について, ゲイリュサック比重 びんを使用してn-ブチルアルコール中， $20^{\circ} \mathrm{C} て ゙$ 求めた。

$\mathrm{SiC}$ の化兴分析はJIS 1096 に従った。すなわち，全ケ イ素の定量は湿式分析法（モリブデン酸ブルー法）で扔 こない，全炭素（TC）打よび遊離炭素（FC）の定量は 堀場製作所製炭素分析装置 EMIA - 110 型を使用し, 燃 焼赤外線吸收法 $\left(1300^{\circ} \mathrm{C}, \mathrm{Sn}\right.$ 助燃剂) で扔てなった。

\section{3 ポリジメチルシランの合成}

ジメチルジクロロシランからポリジメチルシランの合 成，ならびにジフェニルジクロロシランからポリボロジ フェニルシロキサンの合成は文献に従った ${ }^{8)}$ 。ジメチル ジクロロシランからポリジメチルシランを合成した場合 の収摔は65〜 70 wt \%であった。得られたポリジメチル シランの $\mathrm{C}, \mathrm{H}$ 分析値は $\mathrm{C} 41.08 \mathrm{wt} \%, \mathrm{H} 10.37 \mathrm{wt} \%$ (計算值 C $41.30 \mathrm{wt} \%, \mathrm{H} 10.4 \mathrm{wt} \%$ ) であった。

\section{4 ポリカルボシランの合成}

ポリジメチルシランの50 75 g をステンレス製反応容 器にとり,さらに微粉末にしたポリボロジフェニルシロ キサン（3.5 wt％）を加えてよく擋拌した。この反応容 器を Fig. 1 亿示すようにセットして, 窒素ガス霝囲気下 350 ３70 ${ }^{\circ} \mathrm{C}$ で熱重合を㧍てなった。はじめのうちは還 流冷却器から連続的に液滴が落下したが, 熱重合の進行 に伴って液滴の落下はほとんど見られなくなった。ての 段階で重合物の一部を取り出した。この重合物を以下

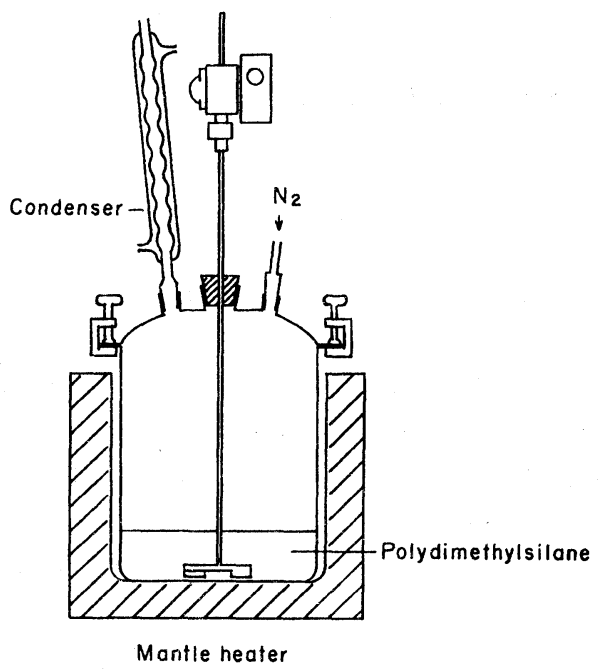

Fig. 1 Apparatus for conversion from polydimethylsilane to polycarbosilane. 
PCS-S 上記す。PCS-S の分子量（Mn）は約 1200 であ つた。擋拌をやめ，さらに熱重合反応を進めて（重合時 間約 3 時間）最終的な形態の発泡状のポリカルボシラン を収率約 $65 \mathrm{wt} \%$ で得た。この形態のポリカルボシラン は溶剤に不溶で，加熱しても不融であった。以下ての三 次元構造物であるポリカルボシランを PCS-I と記す。

\section{3. 結果}

\subsection{IR スペクトル}

PCS-Sと PCS-I の IR スペクトルをポリジメチルシ ランのそ机らと比較して Fig. 2 亿示す。最む特徴的な 変化は，ポリカルボシランの $2100 \mathrm{~cm}^{-1}$ の $\mathrm{Si}-\mathrm{H}$ 伸縮振 動に帰属される吸収 ${ }^{9)}$ がポリジメチルシランには認めら れないととである。その他, ポリジメチルシランからポ リカルボシランへの変化によって, $1400 \mathrm{~cm}^{-1}$ の C- H 变角振動比帰属される吸収は減少し, $1350 \mathrm{~cm}^{-1}$ 之1 100 $\sim 1000 \mathrm{~cm}^{-1}$ の $\mathrm{Si}-\mathrm{CH}_{2}$ - $\mathrm{Si}$ の $\mathrm{CH}_{2}$ の変角振動飞州属 される吸収の強度は增加している ${ }^{9)} 。 1100 \sim 1000 \mathrm{~cm}^{-1}$ は $\mathrm{Si}$ - O の伸縮振動屯現れる領域である ${ }^{10) ~ 12) 。 900 ～ ~}$ $500 \mathrm{~cm}^{-1}$ の領域では，ポリジメチルシランの場合，4つ の吸収ピークが認められる。これらの吸収は主として $\mathrm{CH}_{3}$ 基の変角振動に帰属される。ポリカルボシランでは, こ㧈ら 4 つの吸収の存在は不明瞭で, 全体として $800 \mathrm{~cm}^{-1}$ にピークを持つブロードな吸収となっている（3450〜 $3400 \mathrm{~cm}^{-1}$ 亡 $1620 \mathrm{~cm}^{-1}$ の吸収は $\mathrm{KBr}$ の IR スペクト ルにあ認められたので，乙れらの吸収の強弱について論 じることはできない)。さらに PCS-Sと PCS-IのIR ス ペクトルを比較して見ると，両者間の違いは小さい。主 な変化として $1700 \mathrm{~cm}^{-1}$ の弱い吸収があげられる。乙の

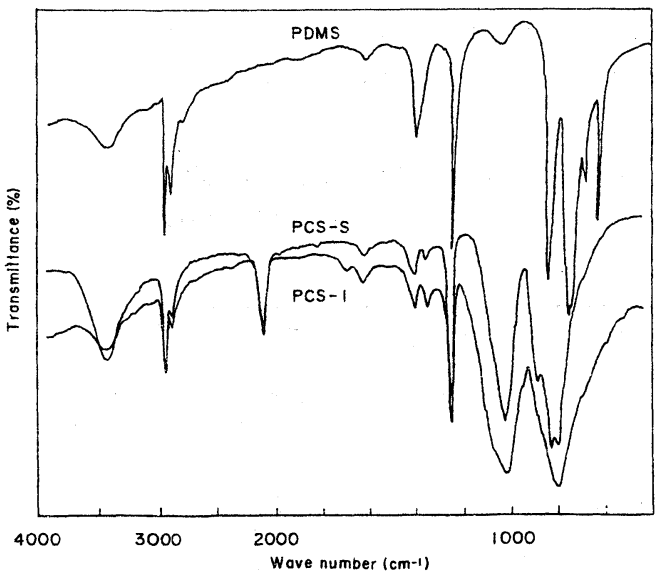

Fig. 2 IR spectra of polydimethylsilane (PDMS), linear polycarbosilane (PCS-S) and crosslinked polycarbosilane (PCI-I).
吸収は PCS-Iには認められるが, PCS-S には認められ ない。乙の吸収の帰属としては $\mathrm{Si}-\mathrm{OH} や \mathrm{C}=\mathrm{O}$ 結合が 考え易いが，三次元化による特徴吸収であるなら， $\mathrm{C}=$ $\mathrm{C}$ 結合の吸収も考慮される。

Fig. 3 は PCS-Iを 700 $1000^{\circ} \mathrm{C}$ の範囲の温度で加熱 処理した場合の $1200 \sim 600 \mathrm{~cm}^{-1}$ の領域における IR ス ペクトルの変化を示す。乙の領域の吸収は高温処理して 屯最後まで残る。 $700^{\circ} \mathrm{C}$ 处理では, $1000 \mathrm{~cm}^{-1}$ と 800 $\mathrm{cm}^{-1}$ とにピークを持つブロードな吸収を示す。 $800{ }^{\circ} \mathrm{C}$ 処理ではこれらの吸収強度は著しく減少し, $1000^{\circ} \mathrm{C}$ 処 理ではほとんど認められなくなる。

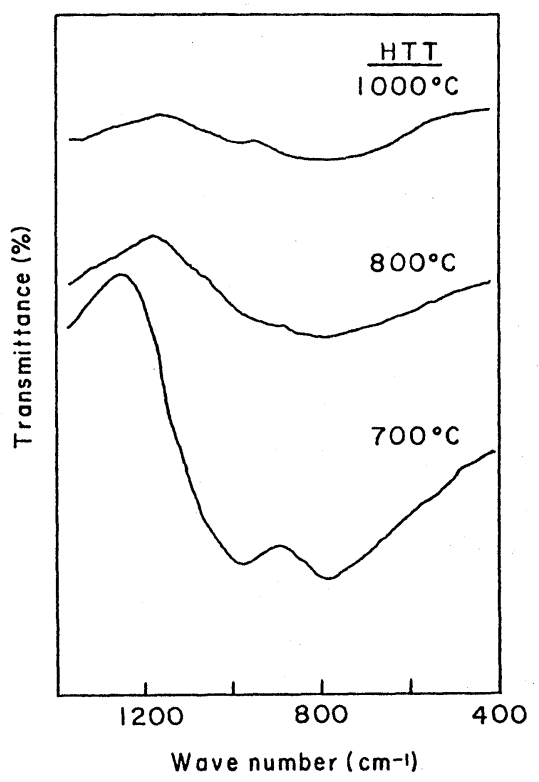

Fig. 3 Change of IR spectrum of PCS-I with heat-treatment temperature in the range of 700 to $1000^{\circ} \mathrm{C}$.

\section{2 熱分 析}

Fig. 4 は PCS-S および PCS-I の熱分解過程を示す。 $\mathrm{DTA}$ から，ポリカルボシランは $450^{\circ} \mathrm{C}$ まで連続した発 熱反応であることがわかる。発熱のピークは280〜 410 ${ }^{\circ} \mathrm{C}$ と $730 \sim 750^{\circ} \mathrm{C}$ にある。 $\mathrm{TG}$ からは， $200^{\circ} \mathrm{C}$ までに わずかな減量があり，200〜 $500^{\circ} \mathrm{C}$ の範囲ではほぼ一定 で，さらに温度が高くなると大きな減量が起こることが 知られる。TGに打ける $200 \sim 500^{\circ} \mathrm{C}$ のプラトーの領域 は測定雾囲気に敏感である。例えば，空気中の測定では このプラト一部分は持ち上がり, 重量増加が起こる。重 合度の差は DTA 上りあ TGに拉いて明瞭に現れている。 すなわち, $200^{\circ} \mathrm{C}$ 以下で起とる減量は PCS-S に比べて PCS-Iの方が小さい。 $200^{\circ} \mathrm{C}$ までの減量は低分子量成 


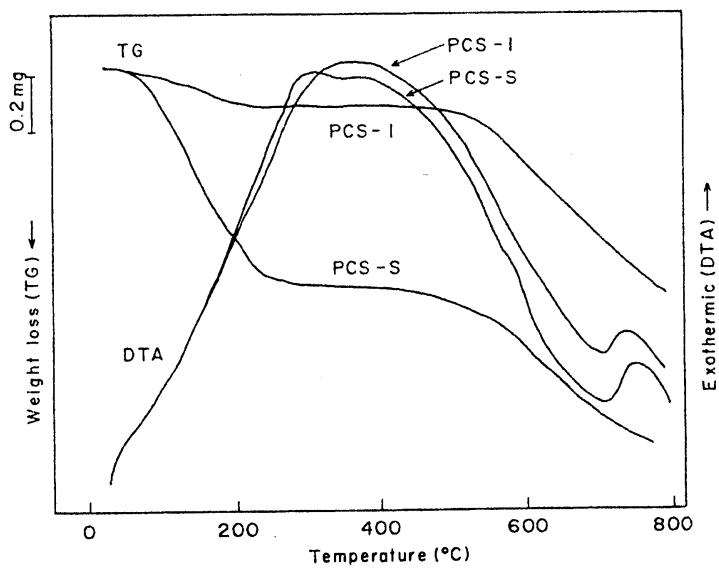

Fig. 4 DTA-TG curves for PCS-S and PCS-I in $\mathrm{N}_{2}$ gas atmosphere.

Heating rate: $10^{\circ} \mathrm{C} / \mathrm{min}$,

Sample weight: $10 \mathrm{mg}$

分の蒸発によるものであり, $410^{\circ} \mathrm{C}$ までの減量を伴わな い発熱反応は熱重合反応汇起因したものであると解釈さ れる。また, $730 \sim 750^{\circ} \mathrm{C}$ の発熱反応は Fig. 3 の IR ス ペクトルの変化を考慮すれば, 主として水素の脱離反応 によるものと考えられる。

\section{$3.3 \mathrm{X}$ 線回折}

PCS-Iを1200 1400 $0^{\circ} \mathrm{C}$ の範囲の温度で加熱処理す ると, 密度 $2.46 \sim 2.5 \mathrm{~g} / \mathrm{cm}^{3}$ の青紫色の光沢を帯びた黒 色物が得られる。乙れら加熱処理物の $2 \theta=10 \sim 80^{\circ}$ の範 囲のX線回折を Fig. 5 亿示す。乙れらの回折線には共 通して $2 \theta=26.5^{\circ}, 35.5^{\circ}, 60.0^{\circ}, 71.7 \sim 71.9^{\circ}$ 亿回折ピ 一クが現れている。回折ピークから同定される結晶系扔 よび面指数を Table 1 亿示す。X 線回折結果は, PCS-I が加熱処理による無機化によって, 立方晶系の $\beta$-SiCに

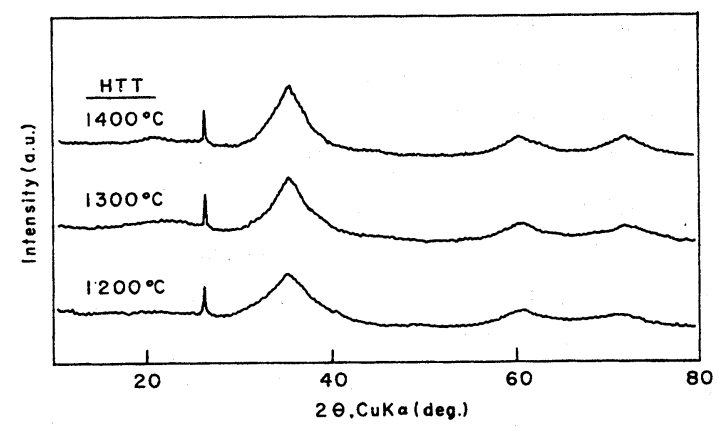

Fig. 5 X-ray diffraction patterns of silicon carbide obtained by PCS-I heat-treated at various temperatures.
Table 1 X-ray diffraction data of silicon carbide synthesized by pyrolysis of polycarbosilane (PCS-I).

\begin{tabular}{|c|c|c|c|}
\hline \multicolumn{2}{|c|}{ Observation } & \multicolumn{2}{|c|}{ Assignment } \\
\hline $2 \theta\left({ }^{\circ}\right)$ & $\mathrm{d}(\mathrm{A})$ & $\mathrm{D}_{h k l}(\mathrm{~A})$ & Material \\
\hline 26.52 & 3.358 & $3.342(101)$ & $\mathrm{SiO}_{2}$ (Hexagonal) \\
\hline 35.50 & 2.526 & $2.51 \quad(111)$ & $\mathrm{SiC}$ (Cubic) \\
\hline 60.02 & 1.54 & $1.54 \quad(220)$ & $\mathrm{SiC}$ (Cubic) \\
\hline 71.69 & 1.315 & $1.31 \quad(311)$ & $\mathrm{SiC}$ (Cubic) \\
\hline
\end{tabular}

変化していることを示す。さらに低温型石英 $\left(\mathrm{SiO}_{2}\right)$ が副成されているととも示している。

\section{4 化学分析}

PCS-Iから得られた炭化ケイ素の Si 量, TC 量扰よ び FC 量の分析值を Table 2 亿示す。 Si 量は 47.48 $48.31 \mathrm{wt} \%$ ，TC 量は32.35〜33.3 wt \%であった。（ $\mathrm{Si}+$ TC）量は80 81 wt\%であるから他の成分 $(\mathrm{X})$ を $20 \mathrm{wt}$ \%含む乙とになる。Fig. 5 の X線回折線から, $\mathrm{SiO}_{2}$ の 存在が明らかであるから，X成分の大部分は酸素である と推定される。X成分が酸素であるとして Si 量, (TCFC) 量㧍よび FC 含量から求めた実験式を次に示す。

$$
\begin{aligned}
& \mathrm{HTT} 1200^{\circ} \mathrm{C}: \mathrm{SiC}_{1.54} \mathrm{C}_{0.094} \mathrm{O}_{1.21} \\
& \text { HTT } 1300^{\circ} \mathrm{C}: \mathrm{SiC}_{1.44} \mathrm{C}_{0.158} \mathrm{O}_{0.732} \\
& \text { HTT } 1400^{\circ} \mathrm{C}: \mathrm{SiC}_{1.23} \mathrm{C}_{0.349} \mathrm{O}_{0.694}
\end{aligned}
$$

乙れらの実験式が示すように, PCS-I の熱分解によっ て合成された炭化ケイ素の $\mathrm{Si} / \mathrm{C}$ 原子比は $1 / 1$ とならず 炭素過剩であり, 炭化ケイ素中には遊離炭素が存在して いる。加熱处理温度変化に注目すると, 処理温度の上昇 と共に原子比は化学量論比に近づいているが, 遊離炭素 量は増加するという結果を与える。

Table 2 Chemical analysis of silicon carbide synthesized by pyrolysis of polycarbosilane (PCS-I).

\begin{tabular}{cccc}
\hline HTT $\left({ }^{\circ} \mathrm{C}\right)$ & $\mathrm{Si}(\mathrm{wt} \%)$ & $\mathrm{TC}(\mathrm{wt} \%)$ & $\mathrm{FC}(\mathrm{wt} \%)$ \\
\hline 1200 & 47.48 & 32.98 & 1.89 \\
& & 33.30 & 1.94 \\
& & & 1.90 \\
1300 & \multirow{4}{*}{47.57} & 32.35 & 3.21 \\
& & 32.56 & 3.19 \\
& & 32.86 & 3.23 \\
1400 & \multirow{2}{*}{48.31} & 32.40 & 7.04 \\
& & 32.35 & 7.38 \\
& & & 7.17 \\
\hline
\end{tabular}




\section{4. 考察}

ジメチルジクロロシランの金属ナトリウムによる脱塩 素反応によってポリジメチルシランを合成した。ポリジ メチルシランは嵩高の白色粉末で, 各種溶剤に不溶であ り, 加熱しても溶融しない。空気中では炎を近づけるだ けで激しく燃え, 易燃焼性を示す。ポリジメチルシランに 重合促進剂としてポリボロジフェニルシロキサンの少量 を添加して, 窒素ガス雾囲気中で $350 \sim 370^{\circ} \mathrm{C}$ で熱重合 すると無色透明のポリカルボシランに変換される。その 際, 重合の程度によって PCS-S P PCS-Iが得られる。 低重合物に属する PCS-S と高重合物の PCS-I との IR スペクトルを比較しても, 両スペクトルは Fig.2 亿示す ようにほぼ一致するから，PCS-I を構成する三次元架 橋構造の単位構造は低重合物のそれと異なるものではな いと言える。

本研究で合成した PCS-Iの IR スペクトルには Si-OH 結合や $\mathrm{C}=\mathrm{O}$ 結合の存在が示唆され, またX線回折線か らは $\mathrm{SiO}_{2}$ の存在が確認された。PCS-I は, 重合反応が 高度に進行した場合に生成する三次元架橋構造を有する 重合物であって, 空気中で加熱して不融化処理を抢てな ったあのではない。従って, PCS-Iの構造中に酸素が 存在することが問題である。酸素は重合促進剤として加 えたポリボロジフェニルシロキサンに含まれる。しかし，ポ リボロジフェニルシロキサンの使用量は少量であるから, PCS - I 亿存在する酸素は PCS-I を空気中で取り扱う時 にあ入ってくると考えられる。PCS - I が酸素と容易に反 応することは空気中での加熱好理によっても確認される。 例えば，PCS-I を空気中 $200^{\circ} \mathrm{C}$ で加熱したら速やかに 発火してゆっくりと燃えた。PCS-Sでは発火現象は見 られなかった。PCS-I は発泡状であるという形態にあ よるが, PCS-Sよりあ構造的に活性度が高いと推定さ れる。そして常温下でも空気中の酸素と容易に反応する と考えられる。

PCS-Iに炭素源としてポリビニルブチラールやポリブ タジェンやピッチを少量添加して粉砕し，乙の混合物を 加熱処理し, 得られた黒色物の X 線回折をおこなうと, Fig. 6 に示すように $2 \theta=26.5^{\circ}$ のピークは消失する。す なわち $\mathrm{SiO}_{2}$ の生成が抑制される。乙の場合では，ポリ カルボシラン中の酸素原子は添加された炭化水素化合物 と反応して $\mathrm{CO}$ や $\mathrm{CO}_{2}$ となって除かれると解釈される。 ポリジメチルシランからポリカルボシランへの熱分解 変換反応は次のように表わされている ${ }^{13)}$ 。

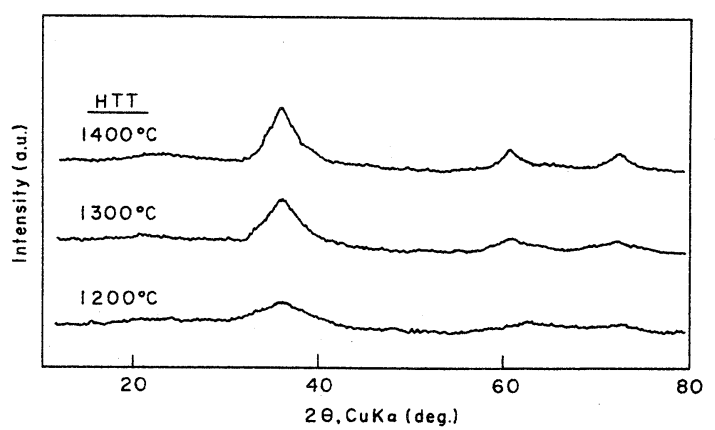

Fig. 6 X-ray diffraction patterns of silicon carbide obtained by PCS-I added polyvinyl butyral and heat-treated at various temperatures.

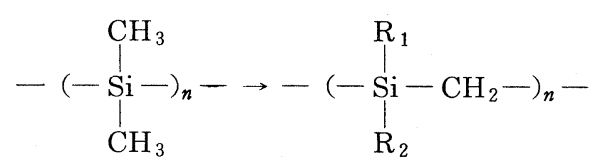

ここで, $\mathrm{R}_{1}, \mathrm{R}_{2}$ は $\mathrm{H}, \mathrm{CH}_{3}$ を示す。熱分解反応は, まず $\mathrm{Si}-\mathrm{Si}$ 結合の切断によって開始され，乙のラジカル がメチル基 $\left(-\mathrm{CH}_{2} ・+・ \mathrm{H}\right)$ と反応することによって 重合反応が進行すると説明されている。乙のメカニズム に従えば, ポリジメチルシランの構造単位にはメチル基 2 個と $\mathrm{Si}-\mathrm{Si}$ 結合が 2 箇所存在するから活性位置が 4 箇 所存在する $\left(・ \mathrm{CH}_{2}-\dot{\mathrm{S}} \mathrm{i}-\mathrm{H}_{2} \mathrm{C} ・\right)$ 乙とにより, 二次 元構造体よりも三次元架橋構造体を形成し易いことがわ かる。従ってポリカルボシランを合成する場合, 一定分 子量の線状構造物を得るには重合条件の厳密なコントロ ールが必要である。乙れに対して三次元架橋構造物とす る場合では合成は容易である。ポリカルボシランの加熱 処理による無機化は, Fig. 3 の IR スペクトルや Fig. 4 の熱分析結果から, $800^{\circ} \mathrm{C}$ 以上の妈理で起こると言える。 さらに, Table 2 の化学分析值やX 線回折結果から, $1200^{\circ} \mathrm{C}$ 処理で十分に炭化ケイ素に変換されることがわ かる。しかし， $\mathrm{Si} / \mathrm{C}$ 原子比は $1 / 1$ でなく炭素が過剩で ある。炭素が過剩であることは，例えば $\mathrm{Si}-\mathrm{C}-\mathrm{C}$ のよう な結合が存在しているととを示唆する。有機ケイ素化合 物の熱分解による炭化ケイ素の合成は一種の濃縮反応之 考えることができ, 加熱処理温度が低い程, 過剩の炭素 が架橋構造中に乱雑に組み込まれていると推定される。

ポリカルボシランから製造される炭化ケイ素瀻維の強 度は $1200^{\circ} \mathrm{C}$ 近傍の処理温度で最高で, $1400^{\circ} \mathrm{C}$ 以上で 急激に減少するてとがわかっている ${ }^{8)}$ 。乙の原因は構造 中に含まれる酸素の離脱と結晶化による構造变化に起因 すると考えられている。本研究結果は, 強度低下が遊離 


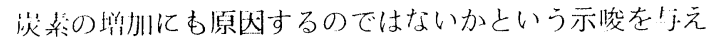
る。

\section{5. まとめ}

ジメチルジクロロシランからポリカルボシランを悀

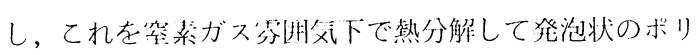
カルボシランを得た。このポリカルボシランを 1200 〜 $1400^{\circ} \mathrm{C}$ で加篎処理して炭化ケイ素とした。この一速の 熱分解過程を検剖するてとによって, 次の内攽が明らか になった。

（1）発泡状ポリカルボシランは構造的に活性で，常温 で究気に触れるととによって容易に酸化される。

(2) 乙のポリカルボシランを $1200 \sim 1400{ }^{\circ} \mathrm{C}$ で加熱 処理するととによって炭化ケイ素が得られるが， $\mathrm{Si} / \mathrm{C}$ モル比は化学量論比でなく炭素が過剩である。加熱処理 温度の上多に伴って Si / C モル比は化”学量論比に近づく が，フリーカーボン量は增加する。特に $1400{ }^{\circ} \mathrm{C}$ 処艮で はフリーカーボン量の增加が著しい。

(3) ポリカルボシランの加熱処理によって $\mathrm{SiO}_{2}$ が缡 成するが，あらかじめ炭素源としてポリビニルブチラー ルやピッチを少量加えて加熱処理すると, $\mathrm{SiO}_{2}$ の生成 は抑制される。

終わりに，文献などで御厚意をいただいた大阪府立大 学の网村清人教授, 東京工業大学工業材料研究所の山田 恵彦博上に感謝の意を表する。
文献

1) P.G. Chantrell, P. Popper, "Special Ceramics 1964", Academic Press, New York (1965) p. 87.

2) W. Verbeek, U.S. Pat. 3853567 (19749).

3) S. Yajima, J. Hayashi and M. Omori, Chem. Lett. 931 (1975).

4) S. Yajima, K. Okamura, J. Hayashi and M. Omori, J. Am. Chem. Soc. 59, 324 (1976).

5) S. Yajima, J. Hayashi, M. Omori and K. Okamura, Nature 261, 683 (1976).

6) 矢鼠聖使他, 特開瞆 51-130324, 51-126300.

7) 阔村清人, 化学:業 65, 65 (1983).

8) 俩村清人, “炭化ケイ素材料”, シーエムシー (1985) p. 22.

9) W.A. Kriner, J. Org. Chem. 29, 1601 (1964).

10) M. Pecottignies, J. Phalippou and J. Zarzycki, J. Mater, Sci, 13, 2605 (1978).

11) R. Hanna, J. Am. Ceram. Soc. 48, 595 (1965).

12) H.W. van der Marel and H. Beutelspacher, "Atlas of Infrared Spectroscopy of Clay Minerals and their Admixtures", Elsevier Scientific Publishing Co., New York (1976) p. 57.

13) Y. Yajima, Y. Hasegawa, J. Hayashi and M. Iimura, J. Mater. Sci. 13, 2569 (1978). 